\title{
Visual outcomes of the diffractive multifocal intraocular lens - Zeiss AT Lisa 809M $\mathrm{M}^{\mathrm{TM}}$
}

\author{
Avaliação do desempenho visual da lente intraocular \\ difrativa multifocal - Zeiss AT Lisa 809M ${ }^{T M}$
}

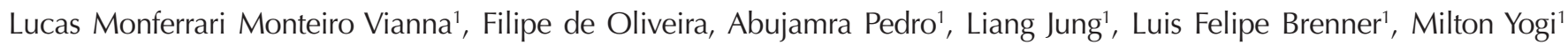

\begin{abstract}
Purpose: To evaluate the visual function of patients with bilateral implantation of multifocal diffractive IOL AT Lisa 809M ${ }^{\mathrm{TM}}$ by visual acuity with and without correction, contrast sensitivity curve, defocus curve and visual function questionnaire (39 VQF). Methods: Interventional clinical prospective study, which evaluated the results of 20 eyes of 10 patients who underwent phacoemulsification and IOL implantation between february and june 2012. Results: The average of residual postoperative ametropia was $0.05 \pm 0.42$ (-0.75 to $+1.25 \mathrm{D})$ spherical diopters and $-0.30 \pm 0.42(0$ to $-1.25 \mathrm{D})$ cylindrical diopters. In the mono and binocular defocus curve, the best visual acuity was obtained with $0.00 \mathrm{D}$ of defocus (far VA). The second peak was obtained with -3.00 D (near vision at $33 \mathrm{~cm}$ ) and among these peaks, it was observed a loss of visual performance with $-2.00 \mathrm{D}$, which corresponds to intermediate vision at $50 \mathrm{~cm}$. Contrast sensitivity was similar to those reported in the literature with this type of $I O L$, both with and without glare, and is shown in the figures. The visual function questionnaire (VFQ-39) had a mean value of $91.91+-6.82$. Conclusion: The diffractive multifocal IOL-AT LISA $809 \mathrm{M}$ presented results consistent with the literature as measured by tests of visual acuity with and without optical correction, contrast sensitivity curve, defocus curve and visual function questionnaire (39 VQF).
\end{abstract}

Keywords: Cataract; Lens implantation, intraocular; Eyeglasses; Visual acuity; Contrast sensitivity; Questionnaires; Treatment outcome

\section{RESUMO}

Objetivo: Avaliar a função visual dos pacientes com implante bilateral da LIO multifocal difrativa AT-Lisa 809 M ${ }^{\mathrm{TM}}$ por meio dos exames de acuidade visual com e sem correção óptica, curva de sensibilidade ao contraste, curva de desfoco e questionário de qualidade de função visual (VQF39). Métodos: Estudo clínico, prospectivo e de intervenção, que avaliou os resultados de 20 olhos de 10 pacientes, submetidos à facoemulsificação e implante de LIO, entre fevereiro e junho de 2012. Resultados: A ametropia residual média pós-operatória foi de $0,05 \pm 0,42(-0,75 \mathrm{a}+1,25 \mathrm{D})$ dioptrias esféricas e $-0,30 \pm 0,42(0$ a $-1,25 \mathrm{D})$ dioptrias cilíndricas. Na curva de desenfoque mono e binocular, a melhor acuidade visual média obtida com $0.00 \mathrm{D}$ de desenfoque (AV de longe). $\mathrm{O}$ segundo pico foi obtido com desenfoque de $-3,00 \mathrm{D}$, o que equivale à visão de perto a $33 \mathrm{~cm}$. Entre esses picos, observamos uma perda de desempenho visual, com desenfoque de $-2,00 \mathrm{D}$, que equivale a visão intermediária a $50 \mathrm{~cm}$. A sensibilidade ao contraste foi similar aos relatados na literatura com este tipo de LIO, tanto com quanto sem ofuscamento, e é mostrada em gráficos. O questionário de função visual (VFQ39) teve valor médio de 91,91 +- 6,82. Conclusão: A LIO multifocal difrativa AT-Lisa 809M ${ }^{\mathrm{TM}}$ (Carl Zeiss Meditec Company - Alemanha) apresentou resultados condizentes com a literatura quando avaliada pelos exames de acuidade visual com e sem correção óptica, sensibilidade ao contraste, curva de desfoco e questionário de qualidade de função visual (VQF 39).

Descritores: Catarata; Implantação de lente intraocular; Óculos; Acuidade visual; Sensibilidade de contraste; Questionários; Resultados de tratamento

${ }^{1}$ Federal University of São Paulo (UNIFESP), São Paulo/SP, Brazil.

Work conducted at the Department of Ophthalmology, Federal University of São Paulo (UNIFESP), São Paulo/SP, Brazil.

The authors declare no conflict of interest.

Received for publication 23/9/2013 - Acceped for publication 17/11/2013

Rev Bras Oftalmol. 2014; 73 (2): 81-5 


\section{INTRODUCTION}

$\mathbf{T}$ Thanks to technological developments in modern cataract surgery, independence from glasses is now of the goals of surgery ${ }^{(1-3)}$.

Among such developments, the most important are increasing biometric accuracy ${ }^{(4-7)}$, greater control over induced astigmatism with small incision techniques ${ }^{(8-10)}$, and improved intraocular lenses (IOLs) ${ }^{(11-18)}$, including more sophisticated multifocal designs.

Multifocal IOLs have been shown to be safe and effective in restoring far and near vision, providing a high degree of independence from corrective lenses ${ }^{(19-25)}$.

The aim of this study was to assess the visual function of patients implanted bilaterally with AT LISA 809M diffractive multifocal IOLs by testing their corrected and uncorrected visual acuity (VA), contrast sensitivity, and defocus curves and applying the visual function questionnaire (VFQ 39).

\section{Methods}

Clinical prospective intervention study assessing 20 eyes of 10 patients submitted to phacoemulsification with implantation of AT LISA 809M diffractive multifocal IOLs. Patients were operated between February and June 2012 at the Cataract Institute (INCAT), Department of Ophthalmology, Federal University of São Paulo (UNIFESP).

Inclusion criteria were patients aged 45-70 years with bilateral cataract requiring surgery, corneal astigmatism under 0.75 $\mathrm{D}$, and pupil diameter of $2.5 \mathrm{~mm}$ or greater. Patients with any prior eye disease that might affect visual performance were excluded from the study.

The study was approved by the Ethics Committee of the Federal University of São Paulo (Opinion number 32453) and followed the provisions of the Declaration of Helsinki. All participants provided their Free and Informed Consent.

\section{Intraocular Lens}

The AT LISA 809M (Carl Zeiss Meditec Company, Germany) is a single-piece diffractive multifocal IOL made of hydrophilic acrylic with a hydrophobic surface specifically designed for implantation in the capsular bag, with the same platform of the Acri.LISA 366D IOL. It is an aspheric refractive IOL with an adding power of $+3.75 \mathrm{D}$ in the lens plane. Its multifocality is due to the presence of concentric rings of different refractive indices.

\section{Surgical Procedure}

All procedures were performed by 2 experienced surgeons (LMMV and PA) under topical anaesthesia (proparacaine hydrochloride $5 \mathrm{mg}$ ); the procedure consisted of phacoemulsification through a $2.75 \mathrm{~mm}$ incision (at the surgeon's discretion) without sutures, with intracapsular implantation of the IOL. There were no surgical complications. Postoperatively, patients were prescribed moxifloxacin (4 times a day for 7 days), dexamethasone $0.1 \%$ (with decreasing dosage) and nepafenac $0.1 \%$ ( 3 times a day for 1 month) eye drops.

\section{Ophthalmic Examination}

Patients underwent a complete preoperative ophthalmic examination. Calculation of the intraocular lens was done by optical biometry using the IOLMaster (Carl Zeiss Meditec Company, Germany) device and the Haigis formula. We chose the IOL that resulted in emmetropia or the nearest negative refraction.

Uncorrected far VA was assessed using a backlit ETDRS (Early Treatment of Diabetic Retinopathy Study) chart under photopic conditions $\left(85 \mathrm{~cd} / \mathrm{m}^{2}\right)$ at a standard distance of 4 metres. Near VA was assessed using a Jaeger chart converted to Snellen's notation. Intermediate VA was assessed using a defocus curve. Values were converted to $\log$ MAR units for each eye and for binocular vision.

The defocus curve was done after recording the VA with lenses of 14 different adding powers at $0.5 \mathrm{D}$ intervals $(-5$ to +3 D). The VA for each lens power was recorded for each eye and for binocular vision. Measurements were done with the Optec 6500P device (Stereo Optical Co., Inc., Chicago, Illinois, USA), with standard assessment of far VA under photopic conditions. Three logarithmic VA charts with different optotype arrangements were used to prevent patients from memorising the chart.

Contrast sensitivity testing utilised the same device, with patients using best correction in test frames under photopic conditions $\left(85 \mathrm{~cd} / \mathrm{m}^{2}\right)$ with and without glare. The test is based on the Functional Acuity Contrast Test (FACT), which assesses the contrast sensitivity curve at five spatial frequencies $(1.5,3.0,6.0$, 12 , and 18 cycles per degree [cpd]).

The visual function questionnaire (VFQ 39) was applied to all patients from the third postoperative month. At all postoperative visits patients were asked whether they were experiencing halos or glare.

\section{Results}

Table 1 shows the demographic data of study subjects, their dependence on glasses, and whether they experienced halos and/or glare.

Figure 1 shows the distribution of patients according to their uncorrected far and near VA (Snellen). The average postoperative residual refractive error was $0.05 \pm 0.42 \mathrm{D}(-0.75$ to $+1.25 \mathrm{D})$ and $-0.30 \pm 0.42 \mathrm{D}$ cyl $(0$ to $-1.25 \mathrm{D}$ cyl $)$.

Figure 2 shows the monocular and binocular defocus curves. The best mean VA was 0.1 LogMAR, obtained with a defocus of $0.00 \mathrm{D}$ (far VA). The second peak had a mean VA of 0.2 to $0.3 \operatorname{LogMAR}$, obtained with a defocus of $-3.00 \mathrm{D}$, which is equivalent to near vision at $33 \mathrm{~cm}$. Between these two peaks there was a loss of visual performance, with a VA of 0.4 to 0.5 LogMAR and a defocus of $-2.00 \mathrm{D}$, which is equivalent to intermediate vision at $50 \mathrm{~cm}$.

Figures 3 and 4 show monocular and binocular contrast sensitivity under photopic and mesopic conditions.

\section{Discussion}

The multifocality of diffractive IOLs is due to the presence of concentric rings of different refractive indices ${ }^{(25)}$. Several studies have shown good outcomes with various multifocal IOLs, including diffractive IOLs ${ }^{(20-27)}$. The outcomes for far VA, with or without correction, seem to be comparable to monofocal lenses. As for uncorrected near vision, multifocal IOLs have shown better results, since the pseudophakic eye loses its accommodation ability ${ }^{(23)}$. The disadvantages of multifocal IOLs are the loss of contrast sensitivity and increased incidence of symptoms such as halos and glare ${ }^{(26)}$. 


\section{Tabela 1}

Demographic data, dependence on glasses, and presence of halos and/or glare.

\begin{tabular}{|c|c|c|c|c|c|c|c|}
\hline Patient & Age & $\operatorname{Sex}$ & Occupation & $\begin{array}{l}\text { Glass } \\
\text { for far } \\
\text { vision }\end{array}$ & $\begin{array}{l}\text { Glass } \\
\text { for near } \\
\text { vision }\end{array}$ & $\begin{array}{c}\text { Glass for } \\
\text { intermediate } \\
\text { vision }\end{array}$ & $\begin{array}{l}\text { Halos or glare/ } \\
\text { Frequency/ } \\
\text { Interfering with } \\
\text { daily tasks }\end{array}$ \\
\hline 1 & 62 & M & Engineer & Yes (occasionally) & No & No & Yes/ Driving at night/ No \\
\hline 2 & 62 & M & Retired & No & No & No & No \\
\hline 3 & 68 & M & Retired & No & No & No & No \\
\hline 6 & 58 & $\mathrm{~F}$ & House wife & No & No & No & No \\
\hline 7 & 52 & $\mathrm{~F}$ & Hair dresser & No & No & No & No \\
\hline 8 & 49 & $\mathrm{~F}$ & House wife & No & No & No & No \\
\hline 9 & 64 & M & Driver & No & No & No & Yes/ Driving at night/ No \\
\hline 10 & 60 & $\mathrm{~F}$ & Seamstress & No & No & No & No \\
\hline
\end{tabular}

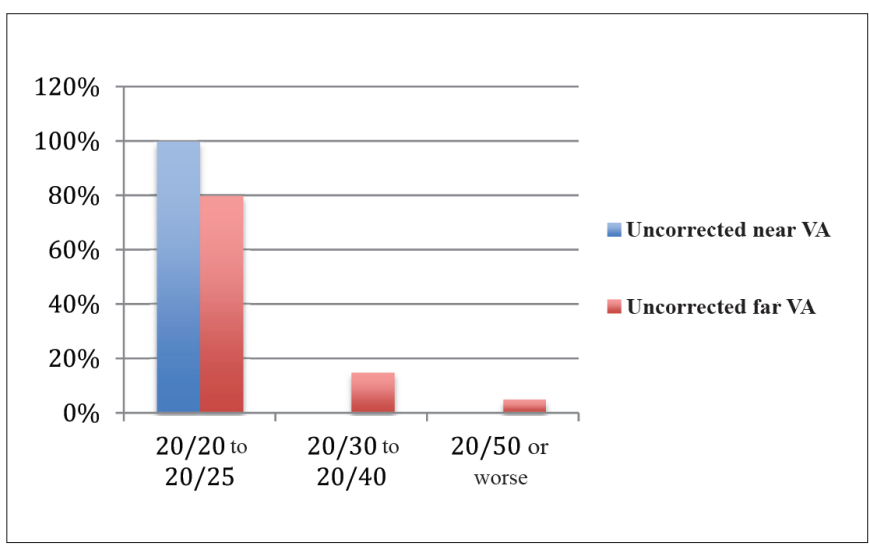

Figure 1. Uncorrected far and near VA.

Our results for monocular uncorrected far and near VA, shown in Figure 1, are in agreement with previous studies that used other multifocal IOLs ${ }^{(20-27)}$. Corrected far and near VA was $20 / 25$ or better in all eyes. The average postoperative residual refractive error was $0.05 \pm 0.42 \mathrm{D}(-0.75$ to $+1.25 \mathrm{D})$ and $-0.30 \pm$ $0.42 \mathrm{D}$ cyl (0 to $-1.25 \mathrm{D}$ cyl), which is consistent with previous studies on multifocal IOLs ${ }^{(20-27)}$. In our study, only one eye of a patient with dense posterior subcapsular cataract had an uncorrected visual acuity of 20/60 (Figure 1) due to biometric error probably secondary to cataract ${ }^{(4)}$. Even though previous studies and the defocus curve indicate a loss of intermediate vision $^{(26)}$, Table 1 shows that no patient required correction for intermediate vision.

Halos and glare are expected photic phenomena after multifocal IOL implantation because of the different light foci created by the rings for far and near vision ${ }^{(26)}$. No patient spontaneously complained of halos or glare. Four patients $(40 \%)$ reported such symptoms when asked about them (Table 1 ).

In the defocus curves, the best mean VA was 0.1 LogMAR, obtained with a defocus of $0.00 \mathrm{D}$ (far VA). A second peak in mean VA (0.2 to 0.3 LogMAR) was found at a defocus of -3.00 $\mathrm{D}$ (near vision at $33 \mathrm{~cm}$ ). Intermediate vision at $50 \mathrm{~cm}$ (at a defocus of $-2.00 \mathrm{D}$ ) showed a decrease in visual performance, with a VA of 0.4 to 0.5 LogMAR. The AT LISA 809M IOL (Carl Zeiss Meditec Company, Germany) is a diffractive multifocal IOL which has the same platform as the Acri.LISA 366D; it is

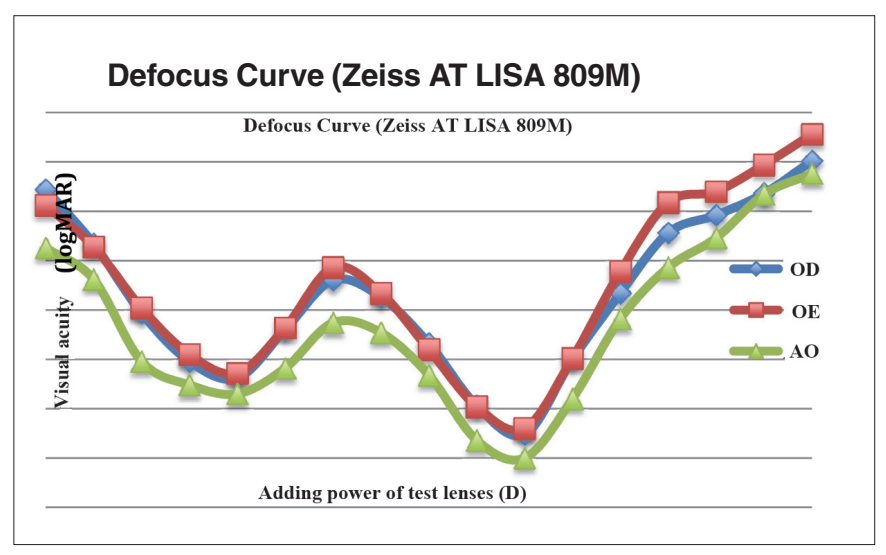

Figure 2. Defocus curve

an aspheric IOL with an adding power of $+3.75 \mathrm{D}$ in the lens plane. The results of our study are consistent with the literature, which shows that this type of IOL provides better far and near vision instead of intermediate vision when compared with refractive IOLs ${ }^{(24-25)}$.

A loss of contrast sensitivity is expected with multifocal IOLs, because light rays are divided into different foci to provide far and near vision ${ }^{(26-29)}$. In our study, the impairment of contrast sensitivity for far vision was consistent with results found in the literature, both with and without glare (Figures 3 and 4). Binocular contrast sensitivity was always better than monocular in both conditions (Figures 3 and 4), which is explained by the effect of binocular summation ${ }^{(26-29)}$.

The mean score obtained in the visual function questionnaire (VFQ-39) was $91.91 \pm 6.82$ (mean score for all 39 questions, ranging from 0 to 100). The questionnaire was not applied preoperatively. However, as shown in Table 1 and comparing our results with previous studies ${ }^{(30,31)}$, the AT LISA 809M IOL provided good patient satisfaction and independence from glasses.

\section{Conclusion}

The AT LISA 809M diffractive multifocal IOL provided satisfactory results for corrected and uncorrected visual acuity, 


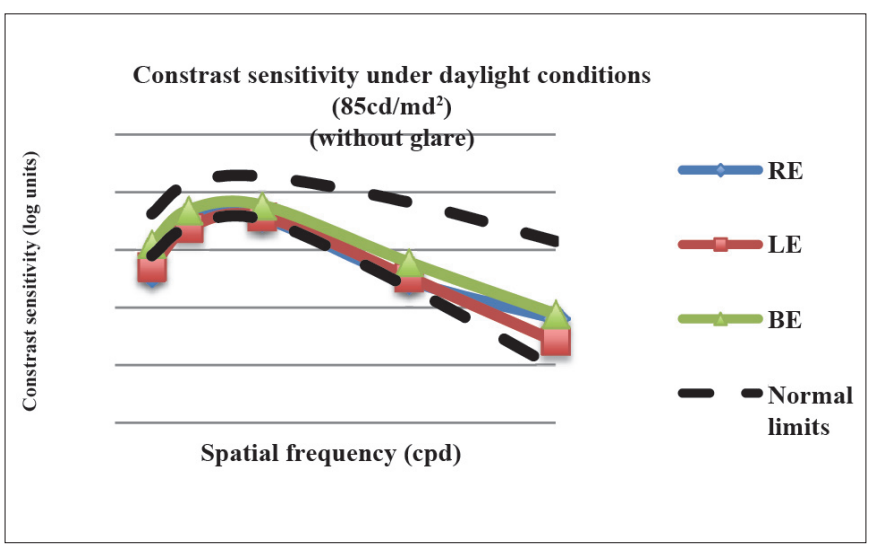

Figure 3. Contrast sensitivity curve for far vision without glare.

contrast sensitivity, defocus curves, and the visual functioning questionnaire (VQF 39), in agreement with the literature. Larger studies are needed to confirm our results and compare them with studies on other IOLs currently available in Brazil.

\section{Acknowledgements}

The authors wish to thank Flávio Hirai for reviewing the statistical methods used in this study.

\section{RefERENCES}

1. Calladine D, Evans JR, Shah S, Leyland M. Multifocal versus monofocal intraocular lenses after cataract extraction. Cochrane Database Syst Rev. 2012;9:CD003169. Review.

2. Hahn U, Krummenauer F, Kölbl B, Neuhann T, Schayan-Araghi K, Schmickler S, et al. Determination of valid benchmarks for outcome indicators in cataract surgery: a multicenter, prospective cohort trial. Ophthalmology. 2011;118(11):2105-12.

3. Lundström M, Barry P, Henry Y, Rosen P, Stenevi U. Evidence-based guidelines for cataract surgery: guidelines based on data in the European Registry of Quality Outcomes for Cataract and Refractive Surgery database. J Cataract Refract Surg. 2012;38(6):1086-93. Review.

4. Lee AC, Qazi MA, Pepose JS. Biometry and intraocular lens power calculation. Curr Opin Ophthalmol. 2008;19(1):13-7. Review.

5. Hoffmann P,Wahl J, Preussner PR. Accuracy of intraocular lens calculation with ray tracing. J Refract Surg. 2012;28(9):650-5.

6. Aristodemou P, Knox Cartwright NE, Sparrow JM, Johnston RL. Intraocular lens formula constant optimization and partial coherence interferometry biometry: Refractive outcomes in 8108 eyes after cataract surgery. J Cataract Refract Surg. 2011;37(1):50-62.

7. Aristodemou P, Knox Cartwright NE, Sparrow JM, Johnston RL. Formula choice: Hoffer Q, Holladay 1, or SRK/T and refractive outcomes in 8108 eyes after cataract surgery with biometry by partial coherence interferometry. J Cataract Refract Surg. 2011;37(1):63-71.

8. Elkady B, Alió JL, Ortiz D, Montalbán R. Corneal aberrations after microincision cataract surgery. J Cataract Refract Surg. 2008;34(1):40-5.

9. Alió J, Rodríguez-Prats JL, Galal A, Ramzy M. Outcomes of microincision cataract surgery versus coaxial phacoemulsification. Ophthalmology. 2005;112(11):1997-2003.

10. Alió JL, Rodríguez-Prats JL, Galal A. MICS: Micro-incision Cataract Surgery. Panamá: Highlights of Ophthalmology International; 2004.

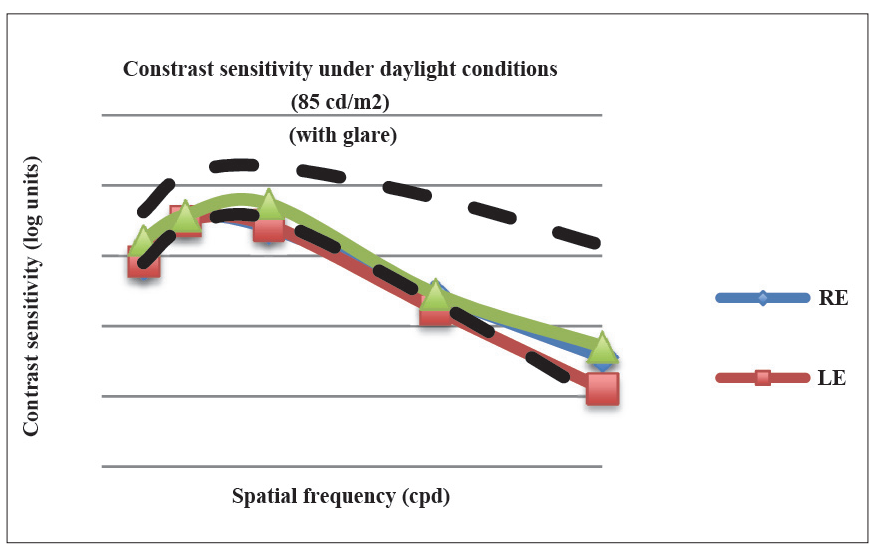

Figure 4. Contrast sensitivity curve for far vision with glare.

11. Denoyer A, Le Lez ML, Majzoub S, Pisella PJ. Quality of vision after cataract surgery after Tecnis Z9000 intraocular lens implantation: effect of contrast sensitivity and wavefront aberration improvements on the quality of daily vision. J Cataract Refract Surg. 2007;33(2):210-6.

12. Pandita D, Raj SM, Vasavada VA, Vasavada VA, Kazi NS, Vasavada AR. Contrast sensitivity and glare disability after implantation of AcrySof IQ Natural aspherical intraocular lens: prospective randomized masked clinical trial. J Cataract Refract Surg. 2007;33(4):603-10.

13. Kurz S, Krummenauer F, Thieme H, Dick HB. Contrast sensitivity after implantation of a spherical versus an aspherical intraocular lens in biaxial microincision cataract surgery. J Cataract Refract Surg. 2007;33(3):393-400.

14. Montard R, Putz C, Creisson G, Montard M. [Aberrometry and contrast sensitivity after cataract surgery: aspherical IOL evaluation]. J Fr Ophtalmol. 2008;31(3):257-62. French.

15. Tzelikis PF, Akaishi L, Trindade FC, Boteon JE. Ocular aberrations and contrast sensitivity after cataract surgery with AcrySof IQ intraocular lens implantation Clinical comparative study. J Cataract Refract Surg. 2007;33(11):1918-24.

16. Muñoz G, Albarrán-Diego C, Montés-Micó R, Rodríguez-Galietero A, Alió JL. Spherical aberration and contrast sensitivity after cataract surgery with the Tecnis Z9000 intraocular lens. J Cataract Refract Surg. 2006;32(8):1320-7.

17. Zeng M, Liu Y, Liu X, Yuan Z, Luo L, Xia Y, Zeng Y. Aberration and contrast sensitivity comparison of aspherical and monofocal and multifocal intraocular lens eyes. Clin Experiment Ophthalmol. 2007;35(4):355-60.

18. Alió JL, Piñero DP, Ortiz D, Montalbán R. Clinical outcomes and postoperative intraocular optical quality with a microincision aberration-free aspheric intraocular lens. J Cataract Refract Surg. 2009;35(9):1548-54.

19. Vilaseca M, Arjona M, Pujol J, Issolio L, Güell JL. Optical quality of foldable monofocal intraocular lenses before and after injection: comparative evaluation using a double-pass system. J Cataract Refract Surg. 2009;35(8):1415-23.

20. Lane SS, Morris M, Nordan L, Packer M, Tarantino N, Wallace RB 3rd. Multifocal intraocular lenses. Ophthalmol Clin North Am. 2006;19(1):89-105, vi. Review.

21. Bellucci R. Multifocal intraocular lenses. Curr Opin Ophthalmol. 2005;16(1):33-7. Review.

22. Dick HB. Accommodative intraocular lenses: current status. Curr Opin Ophthalmol. 2005;16(1):8-26. Review.

23. leyland $\mathrm{M}$, Zinicola E. Multifocal versus monofocal intraocular lenses in cataract surgery: a systematic review. Ophthalmology. 2003;110(9):1789-98.Review. 
24. Alió JL, Tavolato M, De la Hoz F, Claramonte P, Rodríguez-Prats JL, Galal A. Near vision restoration with refractive lens exchange and pseudoaccommodating and multifocal refractive and diffractive intraocular lenses: comparative clinical study. J Cataract Refract Surg. 2004;30(12):2494-503.

25. Alió JL, Elkady B, Ortiz D, Bernabeu G. Clinical outcomes and intraocular optical quality of a diffractive multifocal intraocular lens with asymmetrical light distribution. J Cataract Refract Surg. 2008;34(6):942-8.

26. de Vries NE, Nuijts RM. Multifocal intraocular lenses in cataract surgery: literature review of benefits and side effects. J Cataract Refract Surg. 2013;39(2):268-78. Review.

27. Cillino S, Casuccio A, Di Pace F, Morreale R, Pillitteri F, Cillino G, et al. One-year outcomes with new-generation multifocal intraocular lenses. Ophthalmology. 2008;115(9):1508-16.

28. Kamlesh, Dadeya S, Kaushik S. Contrast sensitivity and depth of focus with aspheric multifocal versus conventional monofocal intraocular lens. Can J Ophthalmol. 2001;36(4):197-201.
29. Hong YT, Kim SW, Kim EK, Kim TI. Contrast sensitivity measurement with 2 contrast sensitivity tests in normal eyes and eyes with cataract. J Cataract Refract Surg. 2010;36(4):547-52.

30. Alió JL, Plaza-Puche AB, Piñero DP,Amparo F, Jiménez R, RodríguezPrats JL, et al. Optical analysis, reading performance, and quality-oflife evaluation after implantation of a diffractive multifocal intraocular lens. J Cataract Refract Surg. 2011;37(1):27-37.

31. Iyigun E, Bayer A, Tastan S, Demiralp M, Acikel C. Validity and reliability study for the NEI-VFO-39 scale in chronic ophthalmic diseases-Turkish version. Acta Ophthalmol. 2010;88(4):e115-9.

\section{Corresponding author:}

Lucas Monferrari Monteiro Vianna, MD

Address: Rua Botucatu, 821 - CEP: 04023-900

São Paulo/SP - Brazil

Telephone: +5511974938000 - Fax: +55115085 2010

e-mail: lucasmmvianna@yahoo.com.br 